\title{
A SIMPLE MACHINE FOR PRODUCING FISH SILAGE
}

\author{
ABDELALEEM K. S., M. A. AL- RAJHI and Y. R. YUSUF \\ Ag. Eng. Res. Institute, ARC, Dokki, Giza
}

(Manuscript received 15 January 2014)

\begin{abstract}
This work was divided into three process (Mincing fish, ensilaging minced material and making pellets containing ensilage minced material) respectively. In the first process the fish was minced at auger speed about $1.1 \mathrm{~m} / \mathrm{s}$ and $4 \mathrm{~mm}$ die diameter to a material with bulk density of about $0.96 \mathrm{~g} / \mathrm{cm}^{3}$. In the second process fish silage was prepared by mixing minced the fish with sufficient formic acid (3.5\% by weight of $85 \%$ formic acid) to lower $\mathrm{pH}$, and bacterial putrefaction was avoided, thus allowing the silage to be stored for several months. In the third process the evaluation was carried out on the machine using four different levels of material moisture content about $(9.1,12.6,15.7$ and $18.2 \%$ wet basis), four different die diameters $[3,4,6$ and $8 \mathrm{~mm}]$ and three levels of auger speeds $[1.1,1.7$, and $2.3 \mathrm{~m} / \mathrm{s}]$. It was observed that the maximum value of pelletizing efficiency (np.),\% were $87 \%$ which was achieved at moisture content (12.6\%), auger speed (2.3 $\mathrm{m} / \mathrm{s}$ ) and die diameter $(3 \mathrm{~mm})$. Minimum value of Broken pellets (Bp) was $6.5 \%$ achieved at moisture content $(12.6 \%)$, auger speed $(2.3 \mathrm{~m} / \mathrm{s})$ and die diameter $(3 \mathrm{~mm})$. Maximum Pellating capacity $(P), \mathrm{kg} / \mathrm{h}$ was $11.3 \mathrm{~kg} / \mathrm{h}$ achieved at moisture content $(18.2 \%)$, auger speed $(2.3 \mathrm{~m} / \mathrm{s})$ and die diameter $(8 \mathrm{~mm})$.
\end{abstract}

\section{INTRODUCTION}

In the last decade, the aquaculture activity in Egypt has been increased and the demand for aquatic feeds was increased too, however the available feed resources in Egypt are limited and there is a large amounts of deteriorated fish wastes discarded daily during catching and marketing process causing pollution.

Fish waste can be advantageously upgraded into fish feed through fish silage conversion. This procedure is safe, cost effective and eco-friendly too (Hanafy and Ibrahim, 2004).

\section{There are two methods of producing fish silage:}

- Addition of acid to minced (Acid silage), which lowers the PH sufficiently to prevent microbial spoilage.

- Bacterial fermentation (fermented silage) initiated by mixing minced fish with a fermentable sugar, which favors growth of lactic acid bacteria.

Formic acid (organic acid) is the best choice for the preparation of chemical silage, the silages made using formic acid are not excessively acidic and therefore do not require neutralization before being used (Oetterer, 2002). Also Opara and AlJufiaili, 2006 added that fish silage or liquefied fish protein is a mixture of fish liquid 
by enzymes in the presence of acids. The acid acts as bacterio-static agent by lowering the $\mathrm{pH}$ of the fish waste to a point where pathogenic and putrefying organisms are not viable. The enzymes are involved in the breakdown of proteins and lipids to amino acids and free fatty acids respectively. Vidotti et al., 2002 showed that fish silage to be highly digestible and an effective replacement for up to $75 \%$ of fish meal in aquafeeds. So the use of fish silage as a substitute for protein ingredients in rations for aquatic organisms is an alternative to solve sanitary and environmental problems caused by the lack of adequate disposition for waste from the fish industry. Besides, it is also a way of decreasing feeding costs, and, consequently, fish production costs, since feeding corresponds to about $60 \%$ of the overall expenses of production (Lia Ferraz de Arruda et al., 2007). The experimental use of fish silage as an alternative protein ingredient in aquafeeds has been widely reported (Arason, 1994, Salah Al-Din, 1995, Faid et al 1997, Wassef et al 2003, Soltan and Tharwat, 2006).

Behnke, 2001 reported that the advantages of pelleting process are:

1-Decrease the feed wastage. 2-Reduce the selective feeding.

3-Decrease the ingredient segregation, less time and energy expended for prehension.

4- Destruction of pathogenic organisms.

5-Thermal modification of starch and protein improved palatability.

Pellets are produced through the process called extrusion. Pelletizing machine comprises of some basic component like the hopper through which the feed meal is feed into the machine, to the pelletizing chamber which consists of the worm, auger or screw (shaft) which propel the feeds. The shaft is controlled manually by the handle which could also be motorized. The output pellet is formed by compacting and forcing through a die opening (with suitable diameter die hole) by a mechanical process Pellets, 2013.

Jannasch et al., 2001 stated that a reduction in screen size from $0.32 \mathrm{~cm}$ to $0.28 \mathrm{~cm}$ for the fine grinding process appeared to produce a modest increase in pellet hardness. Pellet throughout was approximately $2 \mathrm{Mg} / \mathrm{h}$. The bending quality of the feedstock and pellet durability could be improved by changes to the die configuration, steam temperature or natural additives.

Kaddour, 2003 developed a local pelleting machine in the compaction pressure unit by single screw extruder to produce the cook pellets. The optimum results were recorded with the production rate of $362.77 \mathrm{~kg} / \mathrm{h}$, energy requirement of $27.071 \mathrm{~kW} . \mathrm{h} /$ ton, pellets bulk density of $0.91 \mathrm{~g} / \mathrm{cm}^{3}$, pelleting efficiency of $96.092 \%$ and cost of $896.22 \mathrm{LE} /$ ton using screw speed of $1.81 \mathrm{~m} / \mathrm{s}$, fineness degree of $1 \mathrm{~mm}$, effective hole of $25.5 \mathrm{~mm}$ and holes number 22 . Kaddour et al., 2005 studied the 
effect of using stem-lock on the efficiency of extruder pelleting machine to produce the floating fish feed mill pellets. The optimum results were recorded with (392.96 $\mathrm{kg} / \mathrm{h}$ production rate),(93.74\% pelleting efficiency),( $0.6842 \mathrm{~g} / \mathrm{cm}^{3}$ bulk density), (447min.floating time) and (147.73 kW.h/ton energy requirements) using the optimum operation condition of the machine such as (screw type of 4 single screw+1unit twin screw),(number of stemlock of 3 units),(clearance between steamlock and internal case of $1.5 \mathrm{~mm}$ ), and (width of flat sector in steam-lock of 0.048 $\mathrm{Cm}$ ). Morad et al., 2007 studied the effect of some engineering parameters on the performance of fish pelleting machine produce high quality fish pellets. The obtained results revealed that pelleting machine has a high efficiency of $73.15 \%$, high productivity of $422 \mathrm{~kg} / \mathrm{h}$ and minimum production cost of $1150 \mathrm{LE} / \mathrm{Mg}$ at screw speed of $2.11 \mathrm{~m} / \mathrm{s}$ and feed rate of $432 \mathrm{~kg} / \mathrm{h}$. In order to minimize pelleting energy to 50.03 kW.h/Mg and getting high quality fish pellets, effective hole thickness of $15 \mathrm{~mm}$ and 31 die holes were recommended.

\section{Therefore, the objectives of the present study were as follows:}

(a) To develop a meat grinder machine that is affordable by fish farmers for making fish silage as a feed ingredient for Nile tilapia

(b) To test and evaluate the performance of the developed machine under different operational conditions.

(c) To study the best combination of operating parameters for the developed machine that maximize pelletizing efficiency and Pellating capacity, minimize broken pellets and operation cost.

(d) Decreasing the cost of fish feed production with the use of developed machine.

\section{MATERIALS AND METHODS}

\section{Materials}

This study was carried out to test and evaluate the effect of some operating and engineering parameters on the performance of a machine used for mincing fish by-product used for mixing with formic acid (3.5\% by weight of $85 \%$ formic acid is added, that is $35 \mathrm{~kg}$ or about $30 \mathrm{~L}$ of acid to one ton of minced fish) to produce fish silage. The same machine was used after replacing the position of blades and die orifice for making pellets contained, fish silage (Fish meal) (12\%), yellow maize (47.5\%) soybean $(27.5 \%)$, oil $(5 \%)$, wheat bran $(7.5 \%)$, DL.methionine $(0.2 \%)$ and Premix $(0.3 \%)$. Theses percentage were taken from Amria for Fish Feed Meal Company. 
Fish wastes were collected from EL-Gammalia fish market, EL-Dakahlia Governorate. The collected fish wastes were washed and minced using the machine presented in Fig 1.

\section{Instrumentation}

1- Oven:- Samples were oven-dried to constant weight at $105^{\circ} \mathrm{C}$ for a period of 24 hours.

2- Speedometer (tachometer):- A hand Speedometer (HT-5100. Ono Sokki Co, LTD. Japan) with direct reading was used for measuring the speed of rotating shafts.

3- Ordinary balance: - It was used to determine the mass of overall minced and pelletizing samples with an accuracy of one gram.

4- Electrical balance: - Digital electric balance of 200 grams was used to determine the samples mass with an accuracy of $0.0001 \mathrm{~g}$.

5- Graduated glass cylinder (beaker): - A beaker was used to determine the volume of the minced material in density equation.

6- Stop watch:- The time needed for the execution process was measured using a common stop watch with an accuracy of 0.01 second.

7- Measuring tape:- The overall machine dimensions were measured using a steel tape of $2 \mathrm{~m}$ length.

8- Bags: - Plastic bags were used to collect samples.

\section{The main parts of mincing machine}

A. C Motor of $0.56 \mathrm{~kW} 190-380$ Voltage rotates with a speed of $1400 \mathrm{rpm}$. was used to drive the machine.

Figs ( 1 and 2 ) illustrate the main parts of the electrically operated machine that was used for mincing fish by-product. This machine consists of a feeding, mincing, power drive and power transmission units. The feeding unit consists of feeding hopper welded to a cylindrical base, to despose the materials above the mincing machine and allow effective passage of the material with minimum wastage. The mincing unit is made of metal and consists of screw conveyor (auger) which transports fish by-product delivered from the above position to a cutter knife unit consists of 4 blades with a sharp edges and from it to a die orifice $4 \mathrm{~mm}$ hole diameters. An electric motor of $0.56 \mathrm{~kW}(0.75 \mathrm{hp}), 50 \mathrm{HZ}$ and 190-380 V at rotating speed of $1400 \mathrm{rpm}$, three phase was used. The power is transmitted from the motor directly to a main drive shaft by means of a cast iron pulley and V-belt. 


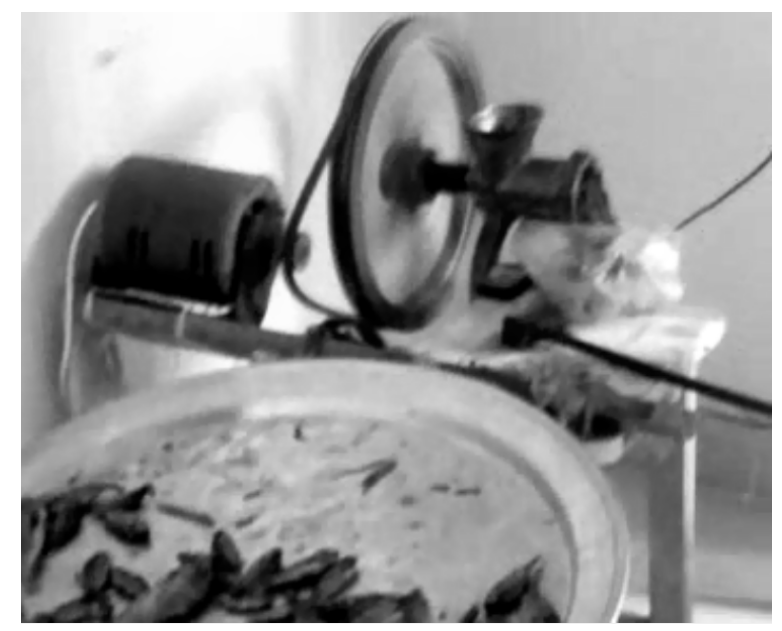

Fig. 1. Schematic diagram of the main parts of the mincing and pelleting machine.

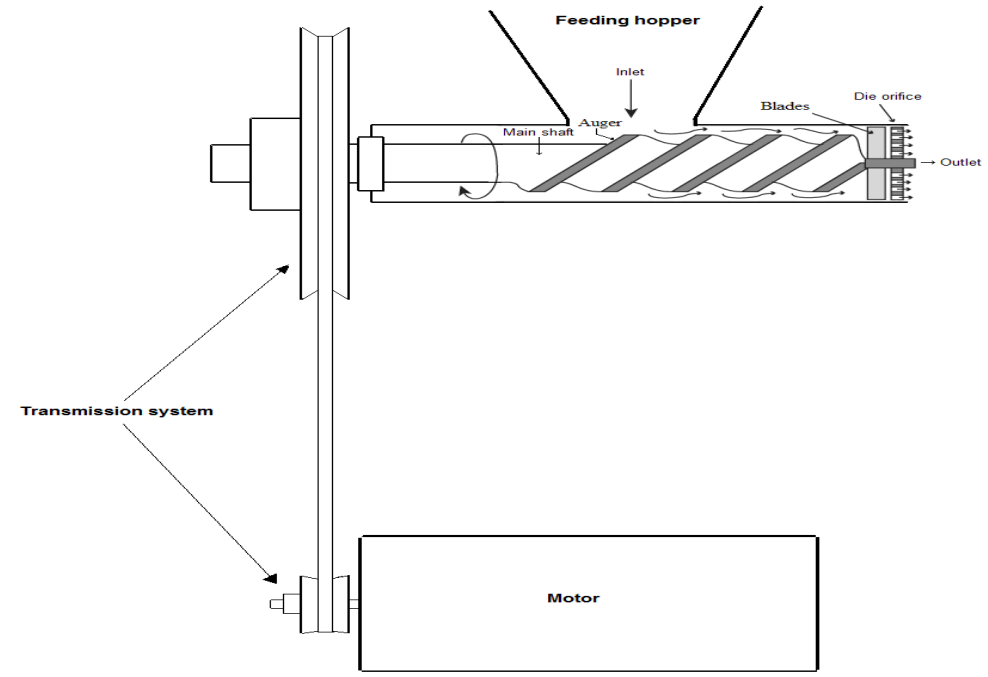

Fig. 2. The machine used for mincing fish by-product

\section{Silage preparation}

Acid silage was prepared by acidifying $5 \mathrm{~kg}$ of minced fish at bulk density of $0.96 \mathrm{~g} / \mathrm{cm}^{3}$ with $3.5 \%$ of formic acid, that is $0.175 \mathrm{~kg}$ or about 0.15 Litter of acid to 5 $\mathrm{kg}$ of minced fish. Stabilized acid, silage was stored at room temperature inside sealed plastic bags until used.

\section{Mixture characterization}

The composition percentages of the experimental fish diets used for fish pelletizing machine is shown in Table 1. 
Table 1. The composition percentages of the experimental fish diets

\begin{tabular}{|l|l|l|}
\hline S/N & FEED INGREDIENTS & $(\%)$ \\
\hline 1 & Wheat bran & 7.5 \\
2 & Fat/Oil & 5 \\
3 & Soybean meal & 27.5 \\
4 & Yellow maize & 47.5 \\
5 & Fish silage & 12 \\
6 & Premix & 0.3 \\
7 & DL.methionine & 0.2 \\
\hline
\end{tabular}

*Taken from Amria for Fish Feed Meal Company.

\section{The main parts of pelletizing machine}

Fig. (3) illustrate the main parts of the machine that was used for fish feed pelletizing. This machine consists of feeding, pelletizing, power drive and power transmission units. The feeding unit consists of feeding hopper, the pelletizing unit is made of Aluminum metal so as to increase its durability and consists of screw conveyor (auger) which transports the feed mixture delivered from above to a die orifice to form pellets and from it to a cutter knife consists of 4 blades with a sharp edges that used to control the pellets length. Dies of 3, 4, 6 and $8 \mathrm{~mm}$ hole diameters were used. An electric motor of $0.56 \mathrm{~kW}(0.75 \mathrm{hp}), 50 \mathrm{HZ}$ and $190-380 \mathrm{~V}$ at rotating speed of 1400 $\mathrm{rpm}$, three phase was used. The power is transmitted from the motor directly to a main drive shaft by means of cast iron pulleys and V-belts. The electric motor has to be moved up and down to be able to match the different pulleys diameter on drum shaft and consequently change the drum speed $(1.1,1.7$ and $2.3 \mathrm{~m} / \mathrm{s})$, respectively.

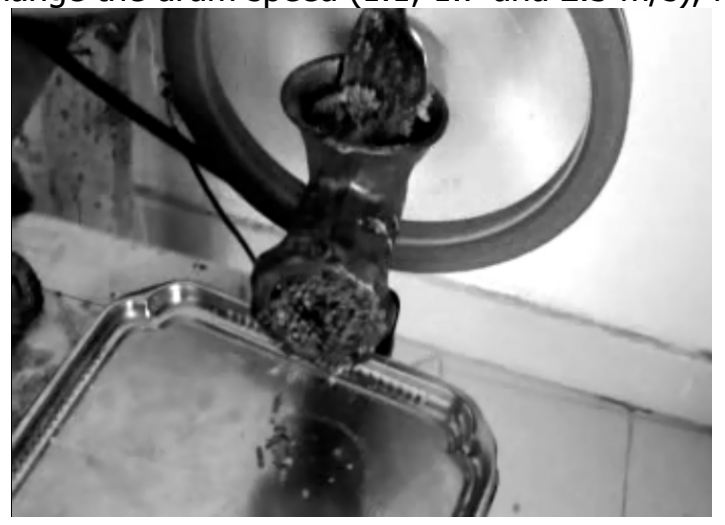

Fig. 3. Pellets made from $12 \%$ silage

\section{Methods}

Initially, twenty kilograms of fish by-product was weighed and put to mince in the meat grinder that fitted with a small motor to increase its power and efficiency. The raw material is first minced, with suitable small particles can be obtained by using meat grinder. The action of mincing allows the natural enzymes and acid to make 
contact with the greatest amount of product as quickly as possible. Immediately after mincing, 3.5 percent by weight of 85 percent formic acid is added, that is $35 \mathrm{~kg}$ or about 30 litres of acid to one ton of fish. It is important to mix thoroughly so that all the fish comes into contact with acid, because pockets of untreated material will putrefy. The acidity of the mixture must be $\mathrm{pH} 4$ or lower to prevent bacterial action. After the initial mixing, the silage formation process starts naturally, but occasional stirring helps to ensure uniformity. The rate of liquefaction depends on the type of raw material, its freshness, and the temperature of the process. Fish offal and fresh fish liquefy much more quickly than stale fish. It should be possible in most installations to mince and add the acid immediately to the raw material as faster as it received, thus avoiding slow liquefaction of stale fish. The warmer the mixture, the faster the process, silage made from fresh fish offal takes about two days to liquefy at $20^{\circ} \mathrm{C}$, but takes $5-10$ days at $10^{\circ} \mathrm{C}$, and much longer at lower temperatures. Thus in winter it would be necessary to heat the mixture initially, or to keep it in a warm area until liquid. Minced untreated fish must be kept covered to keep out flies, once the acid has been added, flies are not attracted to the mixture. Fish silage can be concentrated to reduce its bulk. (Tatterson and Windsor 2001). An experiment to produce fishmeal was carried out after well mixed of raw materials. The materials to be pelletized was weighed to ensure that the feed ingredients are in the correct proportions as formulated in the diet and fed into the hopper throat and due to gravitational action the feed dropped or tamped toward the pelletizing chamber of the machine (comprises of power screw and compression plate) while the power shaft is then rotated in one direction by a small motor and allow the auger to mix and compress the entrapped food and extrudes it through the holes in the die plate. The resulting "spaghetti-like" cylinders of food are cut into short lengths after escaping the die by means of four-blades knifes rotating against the die plate. The operation was based on the principle of axial movement of the feed material in the screw press. The continuous turning of the shaft rotates the screw auger which moves the compressed feed mixture under high compression ratio through die causes pellets of uniform size, shape and density to come out through the holes on the die. The pelletized feeds were then packaged in a polythene and stored in refrigerator at $4^{\circ} \mathrm{C}$.

\section{The studied variables were as follows}

- Moisture content:- The performance evaluation was carried out using three different levels of moisture contents $(9.1,12.6,15.7$ and $18.2 \%$ wet basis) for the feed ingredient named $M_{1}, M_{2}, M_{3}$ and $M_{4}$ respectively.

- Machine speed :- Three different seeds of machine[1.1,1.7 and $2.3 \mathrm{~m} / \mathrm{s}$ ] named $\mathrm{S}_{1}$, $\mathrm{S}_{2}$, and $\mathrm{S}_{3}$, respectively. 
- Die diameters:- Three different die diameters $(3,4,6$ and $8 \mathrm{~mm})$ circular distributed to the area around the plate named $D_{1}, D_{2}, D_{3}$ and $D_{4}$, respectively.

\section{Measurements}

To determine the optimum conditions for the machine under study, the following criteria were studied:

\section{Pelletizing efficiency ( $\boldsymbol{n p}$.), \%}

The pelletizing efficiency $(n p$.$) , \% was determined for 1 \mathrm{~kg}$ of fish feed meal using the following relationship:

$$
\eta_{p}=\frac{W_{o u t}}{W_{\text {in }}} \times 100 \rightarrow(1)
$$

Where:

$W_{\text {out }}=$ Weight of output pelletized feed, $\mathrm{kg}$. and

$W_{\text {in }}=$ Weiaht of total feed insut . ka.

\section{Broken pellet (Bp) ,\%}

(Bp), \% was determined according to the following relationship:

Where:

$\mathrm{W}_{\mathrm{b}}=$ Weight of broken pellets, $\mathrm{kg}$.

$$
\mathrm{Bp}=\frac{W_{b}}{W_{\text {in }}} \times 100 \rightarrow(2)
$$

\section{Pelletizing capacity (P), kg/h}

The productivity of the pelleting machine was determined with the help of a digital stopwatch of $0.1-\mathrm{sec}$. accuracy and an electrical balance of $(0.0001 \mathrm{~g})$ accuracy. Machine productivity (pelletizing capacity) $(\mathrm{P}, \mathrm{kg} / \mathrm{hr}$ ) was calculated as follows:

$$
P=\frac{W_{\text {out }}}{t}, \mathrm{~kg} / \mathrm{h}
$$

Where:

$\mathrm{t}=$ time of test duration (hr.).

\section{Bulk density $(\beta), \mathbf{k g} / \mathrm{m}^{3}$ of material}

It was determined according to ASAE (2003). Samples were taken to determine their mass and volume. The bulk density was calculated as the ratio of the bulk mass and the volume of the container. 


$$
\beta=\mathrm{m} / \mathrm{v} \quad, \mathrm{kg} / \mathrm{m}^{3}
$$

Where:

$\beta$ : is the bulk density of the material, $\mathrm{kg} / \mathrm{m}^{3}$

$\mathrm{m}$ : mass of material in $\mathrm{kg}$, and

$v$ : volume of the container in $\mathrm{m}^{3}$

\section{Data analysis}

All obtained data were tabulated throughout this study after replicated at least three times for each treatment and was analyzed statistically by using a computer program (Minitab Release 15) for estimating the probability at levels 1 and 5\% while the graphs were drawn using the Microsoft excel window 2007.

\section{RESULTS AND DISCUSSION}

\section{Effect of moisture content, \% on Pelletizing efficiency (np., \%), broken pellet ( $B p, \%)$ and pelletizing capacity $(P, \mathbf{k g} / \mathbf{h}$.)}

The pelletizing efficiency, $\%$, broken pellet, $\%$ and pellating capacity $\mathrm{kg} / \mathrm{h}$ were calculated according to equation 1, 2 and 3 respectively. Fig. (4) showed the effect of moisture content, \% on (np), \% , (Bp), \% and (P), $\mathrm{kg} / \mathrm{h}$. Results show that the (np), \% increases from 74 to $87 \%$ with the moisture content up to $12.6 \%$ but from 12.6 to $18.2 \%$ moisture content negative correlation was observed. Increasing the moisture content, from 9.1 to $12.6 \%$ w.b. decreased (Bp), \% from 10 to $6.5 \%$, so the optimum moisture content for excellent performance of the machine is between $9.1-12.6 \%$ wet basis. Increasing moisture content, from 9.1 to $18.2 \%$ increasing $(P), \mathrm{kg} / \mathrm{h}$ from 5.4 to $11.3 \mathrm{~kg} / \mathrm{h}$, so the higher the moisture content the higher the capacity of the machine. It was remarked that (np), increased and (Bp), decreased with moisture content, according to the following descending order $M 1<M 2>M 3>M 4$. The $(P), \mathrm{kg} / \mathrm{h}$ increased with moisture content, \% according to the following descending order $\mathrm{M} 1<\mathrm{M} 2<\mathrm{M} 3<\mathrm{M} 4$. 


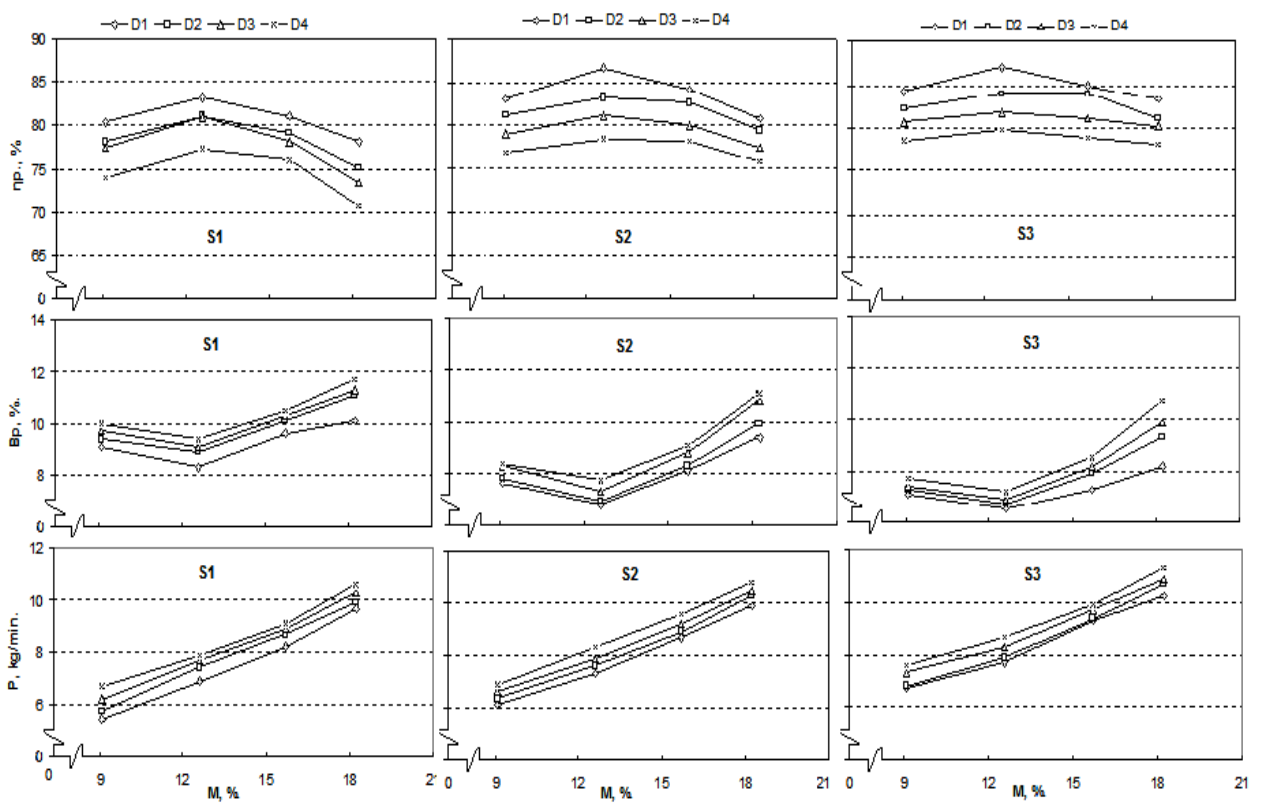

Fig. 4. Effect of material moisture contents, on pelletizing efficiency, $\%$, broken pellet, $\%$ and pelletizing capacity, $\mathrm{kg} / \mathrm{h}$ at different levels of die diameters, $\mathrm{mm}$ and auger speeds, $\mathrm{m} / \mathrm{s}$.

Effect of die diameter on Pelletizing efficiency (np., \%), broken pellet (Bp, $\%)$ and pelletizing capacity $(P, \mathbf{k g} / \mathbf{h}$.)

Fig. (5) shows the effect of die diameter on (np), \% , (Bp), \% and (P), kg/h. Results indicate that increasing die diameter resulted indecrease in (np),\% from 87
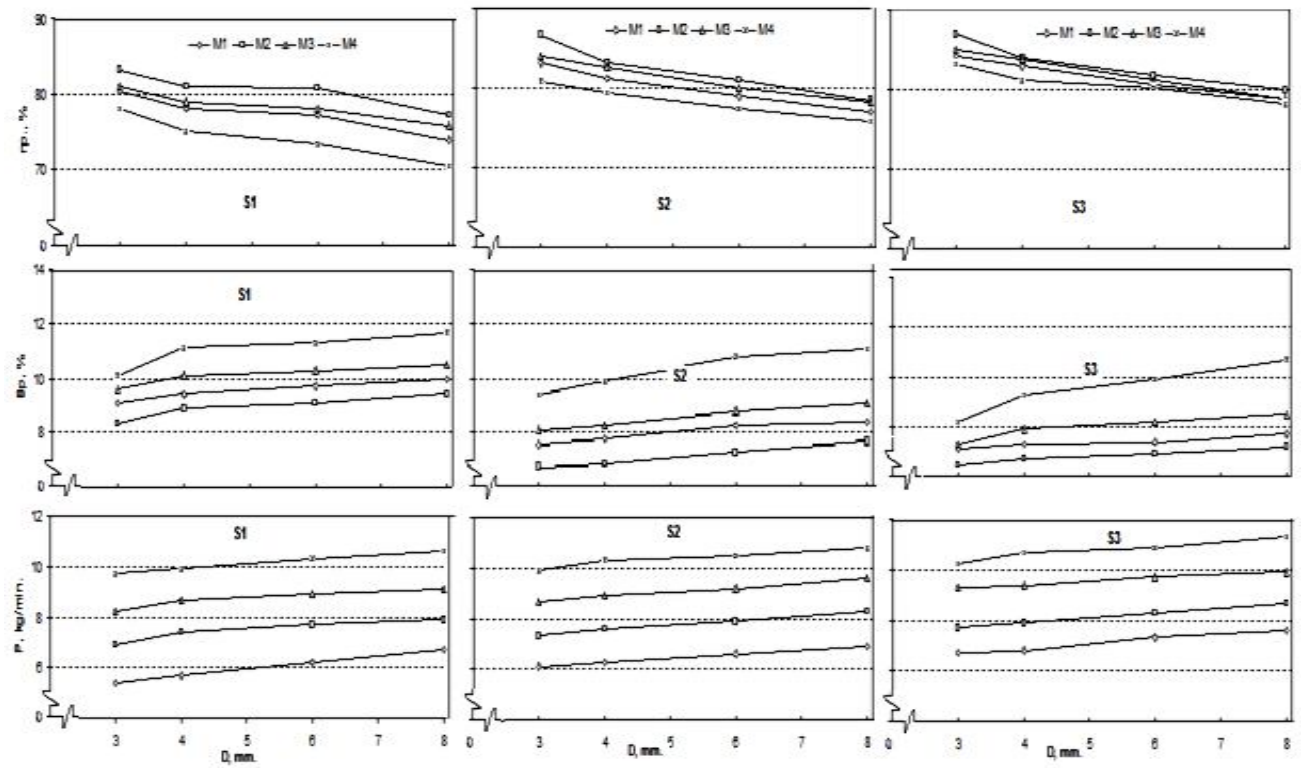

Fig. 5. Effect of die diameters, $\mathrm{mm}$ on pelletizing efficiency, $\%$, broken pellet, $\%$ and pelletizing capacity, $\mathrm{kg} / \mathrm{h}$ at different levels of moisture contents, \% and auger speeds, m/s.

to $70.6 \%$ due to the increase of the die output area that tend to decrease pressure in the pellatizing unit, which causes a decreasing in granules bulking. Results also 
showed that increasing die diameter resulted to increase (Bp), \% and (P), $\mathrm{kg} / \mathrm{h}$ from 6.5 to $11.7 \%$ and from 5.4 to $11.3 \mathrm{~kg} / \mathrm{h}$ respectively. It was remarked that (np), \% decreased, (Bp), \% and (P), $\mathrm{kg} / \mathrm{h}$ increased with increasing die diameter, according to the following descending order $\mathrm{D} 1<\mathrm{D} 2<\mathrm{D} 2<\mathrm{D} 4$.

\section{Effect of auger speeds, $\mathrm{m} / \mathrm{s}$ on Pelletizing efficiency (np., \%), broken pellet} (Bp, \%) and pelletizing capacity ( $P, \mathrm{~kg} / \mathrm{h}$.

Fig. (6) shows the effect of auger speeds, $\mathrm{m} / \mathrm{s}$ on (np), \% , (Bp), \% and (P), $\mathrm{kg} / \mathrm{h}$. Increasing the auger speed from 1.1 to $2.3 \mathrm{~m} / \mathrm{s}$ increasing the (np., \%) from $70.6-87 \%$ due to the increase in both compressing pressure and temperature, that is make the granules mixture in high bulking, and coming out through die in good condition. The lowest percentage of $(\mathrm{Bp}=6.5 \%)$ under auger speeds (S3 $=2.3$ $\mathrm{m} / \mathrm{s})$, and maximum $(\mathrm{P}=11.7 \mathrm{~kg} / \mathrm{h}$.) under auger speeds $(\mathrm{S} 3=2.3 \mathrm{~m} / \mathrm{s})$ may be attributed to the high screw speed which quickly transfer the compressed feed ingredient under high compression ratio through the die.

The above results corroborated the observation of (Rosen and Miller, 1973). They stated that the conveying volume of a screw is a function of the screw speed, diameter and distance between flights of the screw.

It was remarked that (np), \% and (P), $\mathrm{kg} / \mathrm{h}$ increased and (Bp), \% decreased according to the following descending order $\mathrm{S} 1<\mathrm{S} 2<\mathrm{S} 3$.

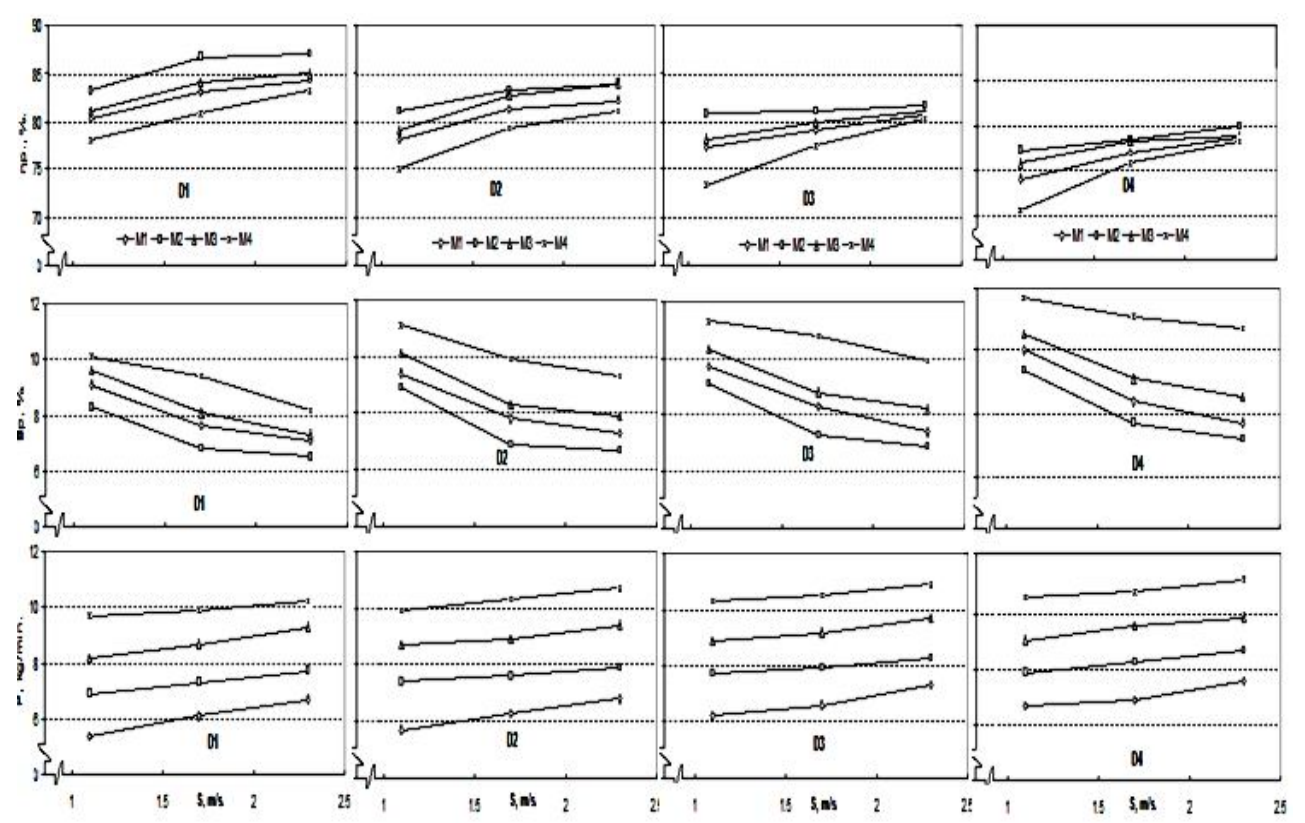

Fig. 6. Effect of auger speeds, $\mathrm{m} / \mathrm{s}$ on pelletizing efficiency, \%, broken pellet, $\%$ and pelletizing capacity, $\mathrm{kg} / \mathrm{h}$ at different levels of moisture contents, \% and die diameters ,mm. 
Data illustrated in Figs. (4 to 6 ) show the comparative magnitude of mean percentage values of pelletizing efficiency (np., \%), broken pellets (Bp, \%) and pelletizing capacity $(P, \mathrm{~kg} / \mathrm{h})$.

The relationships between moisture contents (M, \% w. b.) die diameters ( $D$, $\mathrm{mm})$ and auger speeds $(\mathrm{S}, \mathrm{m} / \mathrm{s})$ on values of pelletizing efficiency (np., \%), broken pellet $(\mathrm{Bp}, \%)$ and pelletizing capacity $(\mathrm{P}, \mathrm{kg} / \mathrm{h}$.) can be represented by the following equations,:

Pelletizing efficiency, $\%=83.0-0.200 M+3.47 S-1.16 D, \quad R^{2}=75.2 \%$

Broken pellet, $\%=7.34+0.224 M-1.66 S+0.219 D, \quad R^{2}=74.6 \%$

Pelletizing capacity, $\mathrm{kg} / \mathrm{h}=0.428+0.426 \%+0.682 \mathrm{~S}+0.182 \mathrm{D}, \quad R^{2}=98.9 \%$

\section{CONCLUSION}

A pelletizing machine for the production of fish feed was developed, and evaluated. The machine showed higher throughput capacity of $11.3 \mathrm{~kg} / \mathrm{h}$ with maximum pelletizing efficiency of $87 \%$. It is recommended to operate the pelletizing machine at materials moisture content of $9.1 \%$, screw speed of $2.3 \mathrm{~m} / \mathrm{s}$ and die diameter of $3 \mathrm{~mm}$ for maximum pelletizing efficiency of $87 \%$. It is recommended to operate the pelletizing machine at moisture content $18.2 \%$, screw speed of $2.3 \mathrm{~m} / \mathrm{s}$ and die diameter $8 \mathrm{~mm}$ for higher throughput capacity of $11.3 \mathrm{~kg} / \mathrm{h}$. It is recommended to operate the pelletizing machine at moisture content $12.6 \%$, screw speed of $2.3 \mathrm{~m} / \mathrm{s}$ and die diameter $3 \mathrm{~mm}$ for lowest percentage of broken pellet 6.5 $\mathrm{kg} / \mathrm{h}$. Generally it is recommended to operate the pelletizing machine at screw speed of $2.3 \mathrm{~m} / \mathrm{s}$ for optimumout put condition. The machine does not make use of steam thereby making it very easy to operate, however, binder could be added to the feed to further strengthen the pelletized feeds. The adoption of the pelletizing machine by small scale and medium scale fish farmers would go a long way in helping them to produce their own feed thereby alleviating the problems associated with the sourcing of imported feeds.

\section{REFERENCES}

1. Arason, S. 1994. Production of fish silage. In: Martin, A.M. (Ed.), Fisheries Processing: Biotechnological Applications. Chapman and Hall, London, pp. 244272.

2. ASAE. 2003. Standard engineering practices data .ISBNO 54-14360 Library of Congress by the American Society of Ag. Eng.: 567-569.

3. Behnke, K. C. 2001. Processing factors influencing pellet quality. Feed Tech, 5 (4), South Africa: 1-15.

4. Faid, M., A. Zouiten, A. Elmarrakchi and B. A. Achkari. 1997. Biotransformation of fish waste into a stable feed ingredient. Food Chem. 60 (1), 13-18.

5. Hanafy, M.A. and S.M. Ibrahim. 2004. Storage stability of yogurt fermented fish silage. J. of Egyptian Academic Social and Environmental Development, 5: 23-41. 
6. Jannasch R., Y. Quan, and R. Samson. 2001. A process and energy analysis of pelletizing switch grass. Final report prepared for natural resources Canada, Alternative Energy Division, Resource Efficient Agricultural Production (REAPCanada), 14 (4): 252-259.

7. Kaddour, U.A.K. 2003. Development of a local pelleting machine to produce fish feed meal cook pellets. The 11th Annual Conference of Misr Society of Agric. Eng. Meet El Deeba, Kafr El-Sheihk, 15-16 October . 538-556.

8. Kaddour,U.A., T.R.Owies and H.A.El-Gendy. 2005. A study on the effect of using steam-lock in extruder pelleting machine to produce floating fish feed pellets. Misr J.Ag.Eng.,22(4):266-293.

9. Lia F., de, A., B. Ricardo and O. Marília. 2007. Use of Fish Waste as Silage - A Review. 50 (5): 879-886. ISSN 1516-8913 Printed in Brazil.

10. Minitab Reference Manuel (release 15), Minitab Inc. State University Michigan.

11. Morad,M., M.K.Afify, U.Kaddour and V.M.Daood. 2007. Study on some engineering parameters affecting the performance of fish feed pelleting machine. Misr J.Ag.Eng., 24(2): 259-282.

12. Oetterer, M., 2002. Industrialização do pescado cultivado. Livraria e Editora Agropecuária, Guaíba: RS-Brasil, 200.

13. Opara, L.U. and S.M. Al-Jufiaili. 2006. Status of fisheries pot harvest industry in the Sultaneof Oman: Part 2 Quantification of fresh fish losses. J. Fisher. Int., 1(24): $150-156$.

14. Pellets. web page Pellets. http://www.wikipedia.org. Internet research in $1 / 08 / 2013$.

15. Rosen J. L. and R. C. Miller. 1973. Food extrusion. Food Technology. 27(8): 4653.

16. Salah AI-Din, S. A. 1995. Studies on unconventional rations in feeding of Nile catfish (Clarias lazerd). M. Sc. Thesis. Fac. Ag., Al-Azhar University, Egypt.

17. Soltan, M. A. and A. A. Tharwat. 2006. Use of fish silage for partial or complete replacement offish meal in diets of Nile tilapia (Oreochromis niloticus) and African catfish \{Clarias gariepinus), Egyptian J. Nutrition andFeeds,9(2):299-314

18. Tatterson, I. N. and M. L. Windsor. 2001. Fish Silage. Ministry of agriculture, fisheries and food torry research station, torry advisory note No. 64. http://www.fao.org/wairdocs/tan/x5937e/x5937e00.htm - Acesso em 14.06.2001.

19. Vidotti, R.M., J.C. Dalton and E.M.M. Viegas. 2002. Acid and fermented silage characterization and determination of apparent digestibility coefficient of crude protein for pacu, Piriactus mesapotamicus. J. World Aqua. Soc. 33 (1), 57-62.

20. Wassef, E. A., M. A. Sweilam and R. F. Attalah. 2003. The use of fermented fish silage as a replacement for fish meal in Nile tilapia (Oreochromis niloticus) diets. Egypt. J. Nut Feed, 6 (Special Issue):357-370. 


\section{آله بسيطة لإنتاج سيلاج الأسماك}

عبـــ العليم خلف سلمان ومحمد علي إبراهيم الر اجحي و يوسف يوسف رمضان رمضان

$$
\text { باحث بمعهُ بحوث الهندسة الزراعية- مركز البحوث الزراعية }
$$

يتتاول هذا البحث ثلاث عمليات ثتمثن في فرم مخلفات الأسماك ثم تحويلها إلي ســيلاج ثــ

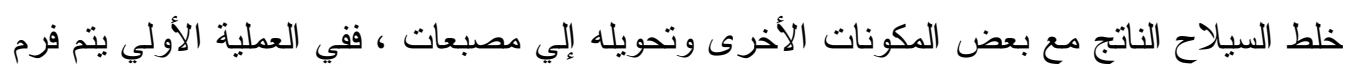

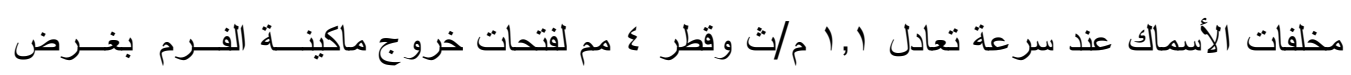

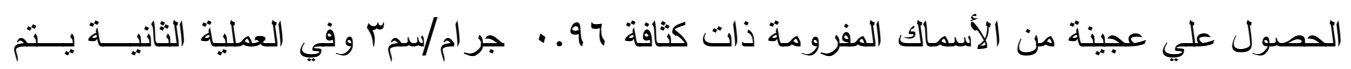

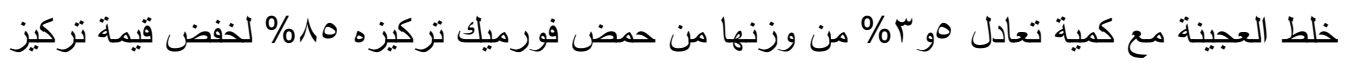

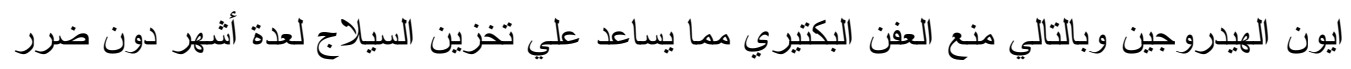

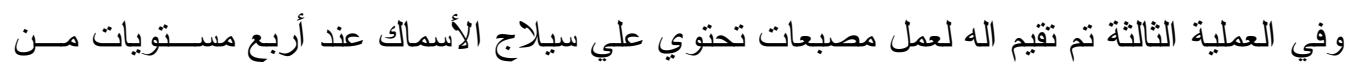

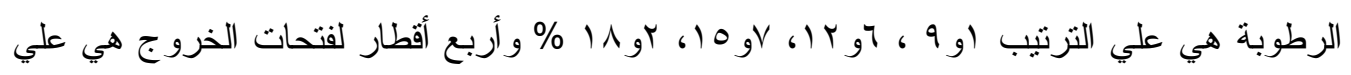

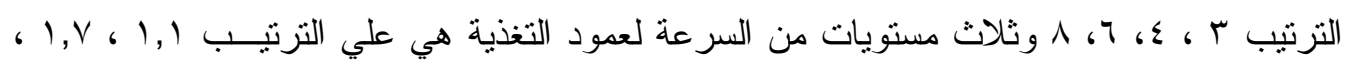

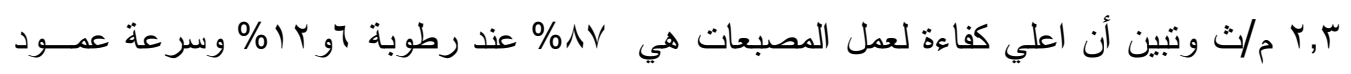

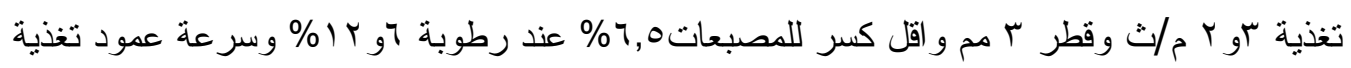

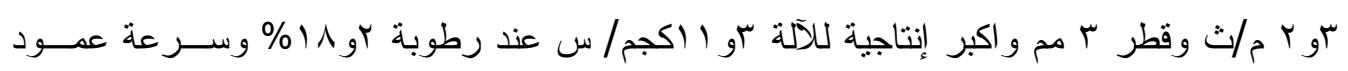

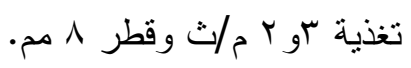

